\title{
ANALISIS PERAMALAN PRODUKSI DAN KONSUMSI DAGING AYAM RAS PEDAGING DI INDONESIA DALAM RANGKA MEWUJUDKAN KETAHANAN PANGAN
}

\author{
Forecasting Analysis of Production And Consumption of Ras Chicken Meat In \\ Indonesia In Order To Make Food Security
}

\author{
Kartika Candra Wibowo ${ }^{1)}$, Deslita Susilo Putri ${ }^{1)}$ dan Sri Hidayati ${ }^{2)}$ \\ ${ }^{1}$ Mahasiswa Magister Teknologi Industri Pertanian, Universitas Bandar Lampung \\ ${ }^{2}$ Staff Pengajar Jurusan Teknologi Hasil Pertanian, Fakultas Pertanian, Universitas Bandar Lampung \\ Jl. Prof. Dr. Soemantri Brodjonegoro Bandar Lampung 35145 \\ e-mail: kartikamtip19@gmail.com
}

\begin{abstract}
Abstrak
Daging ayam ras merupakan salah satu sumber protein hewani dengan harga yang relatif terjangkau dan mudah diperoleh. Permintaan terhadap ayam ras diperkirakan akan terus meningkat. Tujuan dari penelitian ini adalah menganalisis metode peramalan produksi dan konsumsi yang paling sesuai dengan menggunakan software POM-QM Versi 3 sehingga dapat digunakan sebagai dasar dalam penentuan kebijakan demi mewujudkan ketahanan pangan. Peramalan produksi dan konsumsi ayam ras merupakan penentuan tolak ukur untuk meramalkan jumlah produksi dan konsumsi ayam ras sampai tahun 2025. Analisis data menggunakan software POM-QM Versi 3 dengan metode Forecasting : Linear Regression, Moving Average, Weighted Moving Average, Exponential Smoothing dan Exponential Smoothing with Trend. Pengukuran Relatif menggunakan indikator Mean Absolute Deviation (MAD), Mean Squared Error (MSE) dan Mean Absolute Percentage Error (MAPE). Metode peramalan produksi terbaik adalah metode liniear regression dengan nilai MAD sebesar 246.370; MSE sebesar 79.190.061.604 dan MAPE sebesar 9\%. Metode peramalan konsumsi terbaik adalah metode eksponential smoothing with trend dengan nilai MAD sebesar 504,906; MSE sebesar 347.952,60 dan MAPE sebesar 9,8\%. Proyeksi dari produksi pada tahun 2020- 2025 secara berturut- turut yaitu sebesar 4.294.150 ton, 4.784.994 ton, 5.062.790 ton, 5.588.227 ton, 6.131.525 ton dan 6.515.733 ton. Proyeksi dari konsumsi daging ayam ras per kapita per tahun pada tahun 2020- 2025 secara berturut- turut yaitu sebesar 5,708 kg; 5,730 kg; 5,724 kg; 5,734 kg; 5,735 kg dan 5,736 kg.
\end{abstract}

Kata kunci : Daging ayam ras, Konsumsi, Peramalan, Produksi

\begin{abstract}
Broiler chicken meat is one source of animal protein with a relatively affordable price and easy to obtain. The demand for chicken is expected to continue to increase. The purpose of this study is to analyze the most appropriate production and consumption forecasting method using POM-QM Version 3 software. Forecasting of production and consumption of broiler is a benchmark determination to predict the number of production and consumption of broiler until 2025. Data analysis using POM-QM software Version 3 with the Forecasting method: Linear Regression, Moving Average, Weighted Moving Average, Exponential Smoothing and Exponential Smoothing with Trend. Relative measurement uses the Mean Absolute Deviation (MAD), Mean Squared Error (MSE) and Mean Absolute Percentage Error (MAPE) indicators. The best production forecasting method is the linear regression method with a MAD value of 246,370; MSE of 79,190,061,604 and MAPE of 9\%. The best consumption forecasting method is the exponential smoothing with trend method with an MAD value of 504,906; MSE of 347,952.60 and MAPE of 9.8\%. The projection of the production of broiler chicken meat in 2020-2025 are respectively 4,294,150 tons, 4,784,994 tons, 5,062,790 tons, 5,588,227 tons, 6,131,525 tons and 6,515,733 tons. The projection of consumption of broiler chicken meat in $2020-2025$ are respectively $5.708 \mathrm{~kg} ; 5,730 \mathrm{~kg}$; $5,724 \mathrm{~kg} ; 5,734 \mathrm{~kg} ; 5,735 \mathrm{~kg}$ and $5,736 \mathrm{~kg}$ per capita per year.
\end{abstract}

Keywords : Broiler meat, Consumption, Forecasting, Production 


\section{Pendahuluan}

Peningkatan jumlah penduduk, pendapatan dan kesadaran akan gizi menyebabkan permintaan terhadap hasil ternak ayam ras pedaging sebagai sumber protein hewani semakin meningkat. Kebutuhan daging ayam ras secara nasional pada tahun 2018 mencapai 11,5 kg/kapita/tahun. Seiring dengan naiknya pendapatan perkapita penduduk, maka kebutuhan akan protein hewani bagi masyarakat juga meningkat. Ayam ras merupakan salah satu komoditi unggas yang memberikan kontribusi besar dalam memenuhi kebutuhan protein asal hewani bagi masyarakat Indonesia. Ayam ras adalah jenis ternak unggas yang memiliki laju pertumbuhan yang sangat cepat, karena dapat dipanen pada umur 5 minggu. Keunggulan ras didukung oleh sifat genetik dan keadaan lingkungan yang meliputi makanan, temperatur lingkungan, dan pemeliharaan. Kebutuhan daging ayam setiap tahunnya mengalami peningkatan, karena harganya yang terjangkau oleh semua kalangan masyarakat. Pada musim hajatan atau hari besar keagamaan, kebutuhan daging ayam biasanya meningkat sekitar $10 \%-20 \%$ dari kebutuhan normal. Apabila pasokan daging ayam kurang atau lebih rendah dari konsumsi maka akan terjadi kenaikan harga. Sebaliknya apabila pasokan daging ayam melebihi kebutuhan maka harga akan turun.

Peramalan (forecasting) merupakan hal yang penting bagi setiap organisasi bisnis dan untuk setiap pengambilan keputusan manajemen yang sangat signifikan. Peramalan menjadi dasar bagi perencanaan jangka panjang perusahaan. Ketepatan hasil peramalan bisnis akan meningkatkan peluang tercapainya investasi yang menguntungkan perusahaan. Orang bisnis melakukan kegiatan untuk mencapai sesuatu pada waktu yang akan datang serta memperhitungkan kondisi yang mungkin terjadi pada waktu itu. Usaha untuk meminimalkan ketidakpastian itu lazim dilakukan dengan metode atau teknik peramalan tertentu. Sedangkan, menurut Aritonang (2002), peramalan adalah kegiatan untuk memperkirakan apa yang akan terjadi pada masa yang akan datang. Ada banyak jenis peramalan. Misalnya Analisis data menggunakan software POM QM Versi 3 dengan metode Forecasting yaitu : Linear Regression, Moving Average, Weighted Moving Average, Exponential Smoothing dan Exponential Smoothing with Trend.
Pengukuran Relatif menggunakan indikator Mean Absolute Deviation (MAD), Mean Squared Error (MSE) dan Mean Absolute Percentage Error (MAPE).

Tujuan dari penelitian ini adalah menganalisis metode peramalan produksi dan konsumsi yang paling sesuai untuk ayam ras pedaging dalam rangka mewujudkan ketahanan pangan dengan menggunakan Software POM-QM for Windows Version 3. Peramalan adalah suatu proses untuk menduga kejadian yang akan datang dimasa akan datang dengan tujuan untuk mengurangi risiko (Yogi, 2018). Peramalan produksi dan konsumsi ayam ras merupakan penentuan tolak ukur untuk meramalkan jumlah produksi dan konsumsi ayam ras pedaging Indonesia dimasa yang akan datang yaitu pada tahun 2020 sampai tahun 2025 .

\section{Metode Penelitian}

Metode penelitian ini menggunakan Studi literatur dan kepustakaan yang bertujuan untuk dapat menganalisa secara teoritis terhadap masalah-masalah yang berhubungan dengan penulisan tesis. Studi kepustakaan dilakukan dengan membaca berbagai text book, jurnal dan artikel yang relevan serta sumber-sumber lain guna memperoleh data sekunder. Pada penelitian ini dilakukan pengumpulan data yang berkaitan dengan data produksi dan konsumsi daging ayam ras pedaging di Indonesia. Data diperoleh dari Direktorat Jenderal Peternakan dan Kesehatan Hewan. Dalam buku Statistik Peternakan Dan Kesehatan Hewan 2019. Dilakukan perbandingan hasil peramalan antara metode Forecasting yaitu : Linear Regression, Moving Average, Weighted Moving Average, Exponential Smoothing dan Exponential Smoothing with Trend. Pengukuran Relatif menggunakan indikator Mean Absolute Deviation (MAD), Mean Squared Error (MSE) dan Mean Absolute Percentage Error (MAPE). Lalu dilakukan pemilihan metode yang paling akurat dalam meramalkan produksi dan konsusmi ayam pedaging nasional. Untuk proses perhitungan dibantu dengan menggunakan software POM QM Versi 3.

\section{Pemodelan Penjualan (Forecasting)}

Analisis peramalan (forecasting)/pemodelan produksi dan konsumsi menggunakan beberapa metode yaitu Linear Regression, Moving Average, 
Weighted Moving Average, Exponential Smoothing, dan Exponential Smoothing with Trend.

\subsection{Linear Regression}

Linear regresi merupakan metode peramalan dengan model regresi yang paling sederhana melibatkan sebuah variabel tak bebas dan sebuah variabel bebas dimana hubungan keduanya proporsional secara linier (Assauri, 2004). Bentuk model Linear Regression yaitu:

$$
\begin{aligned}
& \mathrm{Y}^{\prime}=\mathrm{a}+\mathrm{bX} \\
& \text { Keterangan: } \\
& Y^{\prime} \quad=\text { Nilain............ } 1 \text { yang diramalkan } \\
& \mathrm{a} \quad=\text { Konstanta (intercept) } \\
& \mathrm{b} \quad=\text { Koefisien regresi (slope) } \\
& \mathrm{X} \quad \text { =Variabel yang mempengaruhi (waktu: } \\
& \quad \text { tahun, bulan, hari) }
\end{aligned}
$$

\section{$1.2 \quad$ Moving Average}

Moving Average merupakan metode peramalan yang didasarkan pada rata-rata aritmatika yang didapatkan dari data di masa lampau (Baroto, 2002). Bentuk dari metode Moving Average adalah :

$$
\mathrm{Y}^{\prime}{ }_{t+1}=\frac{\mathrm{T}_{\mathrm{t}-\mathrm{n}+1}+\cdots+\mathrm{T}_{\mathrm{t}+1}+\mathrm{T}_{\mathrm{t}}}{\mathrm{n}}
$$

Keterangan:

$$
\begin{array}{ll}
\mathrm{Y}^{\prime}{ }_{t+1} & =\text { Nilai peramalan periode } \mathrm{t}+1 \\
\mathrm{~T}_{\mathrm{t}} & =\text { Nilai rill periode ke-t } \\
\mathrm{n} & =\text { Jumlah deret waktu yang digunakan }
\end{array}
$$

\subsection{Weighted Moving Average}

Weighted Moving Average merupakan metode peramalan dengan menggunakan deret waktu lampau dan dilakukan pembobotan tertentu. Nilai pembobotan yang diberi bias berbeda-beda (Handoko, 2014). Bentuk metode Weighted Moving Average adalah:

$$
Y^{\prime}{ }_{t}=\frac{\mathrm{W}_{1} A_{t-1}+W_{2} A_{t-2}+\cdots+W_{n} A_{t-n}}{n}
$$

Keterangan:

$Y^{\prime}{ }_{\mathrm{t}} \quad=$ Nilai peramalan periode $\mathrm{t}$

$\mathrm{W}_{1}$ = Bobot yang diberikan pada periode $\mathrm{t}-1$

$\mathrm{W}_{2}$ = Bobot yang diberikan pada periode $\mathrm{t}-2$

$\mathrm{W}_{\mathrm{n}} \quad$ = Bobot yang diberikan pada periode $\mathrm{t}-\mathrm{n}$

$\mathrm{n} \quad=$ Jumlah periode

\subsection{Exponential Smoothing}

Exponential Smoothing adalah suatu metode peramalan dengan prosedur yang secara terus menerus memperbaiki peramalan (smoothing) dengan merata-ratakan nilai masa lalu dari suatu data deret waktu dengan cara menurun (exponential) (Indrajit dan Djokopranoto, 2003). Bentuk model Exponential Smoothing adalah:

Keterangan:

$$
S_{\mathrm{t}}=\alpha * \mathrm{Xt}+(1-\alpha) * S_{t-1}
$$

$S_{t} \quad=$ Peramalan untuk periode $\mathrm{t}$

$\mathrm{S}_{\mathrm{t}-1} \quad=$ Peramalan pada waktu $\mathrm{t}-1$

$\alpha=$ Konstanta perataan antara 0 dan 1

$\mathrm{Xt}+(1-\alpha)=$ Nilai aktual time series

\subsection{Exponential Smoothing with Trend}

Exponential Smoothing with Trend adalah metode peramalan dengan memberi nilai pembobot pada serangkaian pengamatan sebelumnya untuk memprediksi masa depan (Rangkuti, 2004). Bentuk model Exponential Smoothing with Trend adalah :

$$
\mathrm{T}_{\mathrm{t}}=\beta\left(\mathrm{S}_{\mathrm{t}}-\mathrm{S}_{\mathrm{t}-1}\right)+(1-\beta) \mathrm{T}_{\mathrm{t}-1}
$$

Keterangan:

$\mathrm{T}_{\mathrm{t}} \quad=$ Peramalan untuk periode $\mathrm{t}$

$\mathrm{T}_{\mathrm{t}-1}=$ Peramalan pada waktu $\mathrm{t}-1$

$\beta=$ Konstanta dengan nilai antara 0 dan 1

$\mathrm{S}_{\mathrm{t}}{ }^{\prime}=$ Permintaan nyata periode $\mathrm{t}$

$\mathrm{S}_{\mathrm{t}-1}=$ Permintaan nyata periode $\mathrm{t}-1$

\section{Pengukuran Relatif}

Pengukuran relatif merupakan suatu cara yang digunakan untuk mengetahui besar kesalahan sebuah peramalan. Besar kesalahan sebuah peramalan (nilai eror) dapat diketahui dengan menghitung selisih antara nilai asli dengan nilai ramalan (Subagya, 1994). Pengukuran kesalahan dari suatu metode peramalan yang dihasilkan dapat dilakukan dengan cara sebagai berikut:

\subsection{Mean Absolute Deviation (MAD)}

Mean Absolute Deviation (MAD) merupakan ukuran utama dari kesalahan perkiraan dari seluruh model peramalan. Nilai eror dihitung dengan membagi jumlah nilai absolut dari kesalahan perkiraan dengan jumlah periode. Mean Absolute Deviation (MAD) paling berguna ketika 
orang yang menganalisa ingin mengukur kesalahan ramalan dalam unit yang sama sebagai deret asli.

$$
\mathrm{MAD}=\frac{\sum|D t-F t|}{\mathrm{n}}
$$

Keterangan:

$D t \quad=$ Nilai yang sebenarnya pada masa- $t$

$\mathrm{Ft}=$ Nilai yang diramalkan pada masa- $\mathrm{t}$

$n$ = jumlah masa yang dicakup

\subsection{Mean Squared Error (MSE)}

Mean Squared Error (MSE) adalah metode lain untuk mengevaluasi metode peramalan. Masingmasing kesalahan atau sisa dikuadratkan. Kemudian dijumlahkan dan dibagi dengan jumlah observasi. Pendekatan ini mengatur kesalahan peramalan yang besar karena kesalahan-kesalahan itu dikuadratkan. Kelemahan dari menggunakan Mean Squared Error (MSE) adalah bahwa ia cenderung untuk menonjolkan penyimpangan besar karena istilah kuadrat.

$$
\mathrm{MSE}=\frac{\sum(D t-F t)^{2}}{\mathrm{n}}
$$

Keterangan:

$$
\begin{array}{ll}
\mathrm{Dt} & =\text { Nilai yang sebenarnya pada masa-t } \\
\mathrm{Ft} & =\text { Nilai yang diramalkan pada masa-t } \\
\mathrm{n} & =\text { jumlah masa yang dicakup }
\end{array}
$$

\subsection{Mean Absolute Percentage Error (MAPE)}

Masalah dengan MAD dan MSE adalah bahwa nilai-nilai mereka bergantung pada besarnya item yang diperkirakan. Jika item yang diramalkan dalam ribuan, maka MAD dan MSE bisa sangat besar. Untuk menghindari masalah tersebut, kita dapat menggunakan metode Mean Absolute Percentage Error (MAPE). MAPE mengindikasi seberapa besar kesalahan dalam meramal yang dibandingkan dengan nilai nyata pada deret. Metode MAPE digunakan untuk membandingkan ketepatan dari teknik yang sama atau berbeda dalam dua deret yang sangat berbeda dan mengukur ketepatan nilai dugaan model yang dinyatakan dalam bentuk rata-rata persentase absolut kesalahan. MAPE dapat dihitung dengan rumus sebagai berikut:

$$
\text { MAPE }=\frac{\sum|D t-F t|}{\sum D t}
$$

Keterangan:

$$
\text { Dt = Nilai yang sebenarnya pada masa- } \mathrm{t}
$$

$$
\mathrm{Ft}=\text { Nilai yang diramalkan pada masa- } \mathrm{t}
$$

\section{HASIL DAN PEMBAHASAN}

\section{Peramalan Produksi Daging Ayam Ras Pedaging di Indonesia}

Pergerakan produksi daging ayam ras pedaging di Indonesia memiliki trend meningkat dan dapat diprediksikan meningkat untuk tahun selanjutnya. Hal ini dibuktikan oleh hasil regresi trend untuk series produksi daging ayam ras pedaging yang menunjukkan bahwa variabel trend signifikan secara statistik dan memiliki koefisien positif. Dari tahun 2015 sampai tahun 2019 terus mengalami peningkatan pada Gambar 1 di bawah ini.

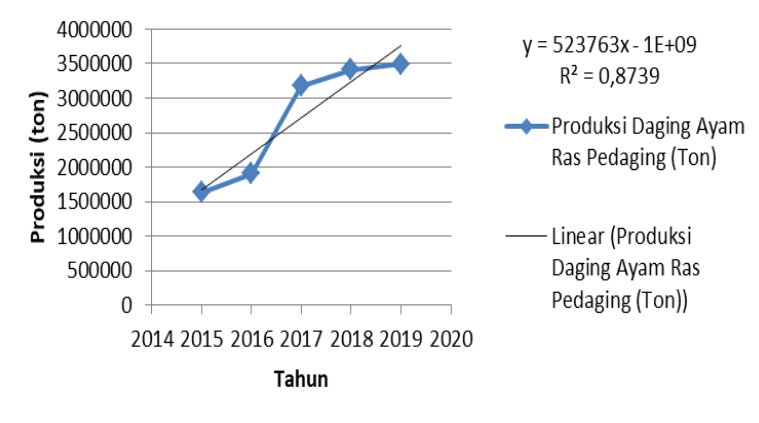

Gambar 1. Produksi daging ayam ras pedaging di Indonesia tahun 2015 - 2019 (Ditjen. PKH)

Pada kurun 2015 - 2019 produksi daging ayam ras terus mengalami peningkatan dengan rata-rata jumlah peningkatan sejumlah 23,4\% seperti yang dapat dilihat pada gambar 1 .

Penulis melakukan peramalan dengan berdasarkan data produksi daging ayam ras pedaging di Indonesia. Data tersebut diperoleh dari studi literatur dengan mengambil data dari direktorat jenderal peternakan dan kesehatan hewan kementrian pertanian 2019. Selanjutnya penulis melakukan pengolahan data menggunakan bantuan software POM-QM for Windows Versi 3.

Berdasarkan metode yang telah dijelaskan di atas, penulis melakukan analisa data dengan pendekatan forcasting berdasarkan time series analysis. Metode yang digunakan adalah linear regression, moving average, weighted moving average, eksponential smoothing, dan eksponential smoothing with trend. Berikut ini diperoleh hasil 
perhitungan peramalan yang disajikan pada Tabel 1 di bawah ini.

Tabel 1. Hasil peramalan produksi daging ayam ras pedaging di Indonesia

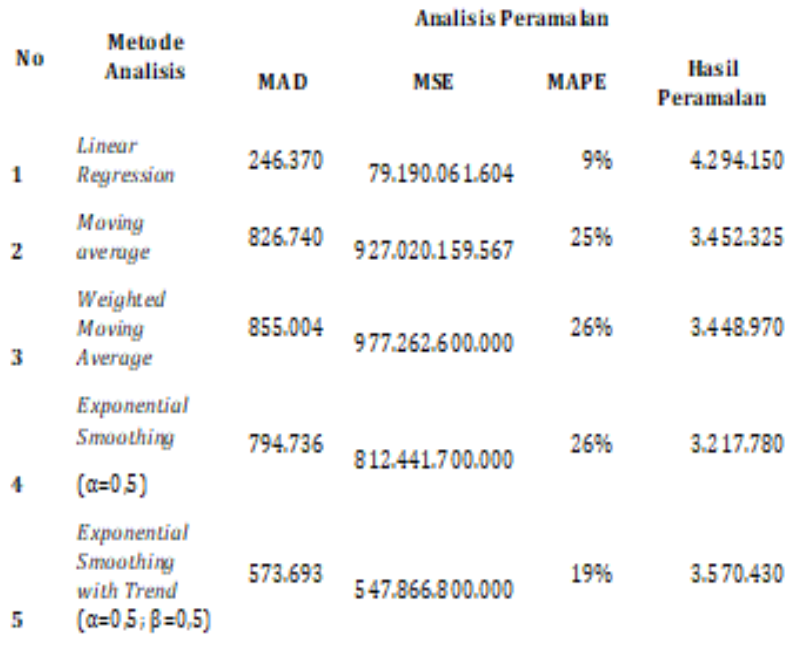

Penulis melakukan peramalan dengan beberapa metode yang digunakan dengan tujuan agar memperoleh metode yang paling akurat berdasarkan tingkat eror dari metode-metode yang digunakan. Selanjutnya tingkat akurasi dari metode tersebut dinilai dengan MAD, MSE dan MAPE. Metode yang memiliki tingkat eror yang lebih kecil menandakan bahwa metode tersebut merupakan metode peramalan yang lebih akurat.

Metode peramalan yang memiliki tingkat eror yang paling kecil adalah liniear regression yang ditunjukan dengan nilai rangking paling kecil, sedangkan nilai rangking terbesarnya adalah metode moving average. Metode peramalan yang memiliki tingkat eror yang paling kecil adalah liniear regression. Nilai akurasi dari metode liniear regression terdiri dari MAD sebesar 246.370; MSE sebesar 79.190.061.604 dan MAPE sebesar 9\%. Kemudian urutan kedua adalah metode exponential smoothing with trend menggunakan $\alpha=0.5$ yang mendapatkan nilai akurasi MAD sebesar 573.693; MSE sebesar 547.866.800.000 dan MAPE sebesar 19\%. Urutan ketiga adalah exponential smoothing yang memiliki nilai akurasu MAD sebesar 794.736; MSE sebesar 547.866.800.000; dan MAPE sebesar $26 \%$. Kemudian urutan keempat adalah metode Moving average yang mendapatkan nilai akurasi MAD sebesar 826.740; MSE sebesar 927.020.159.567 dan MAPE sebesar 25\%. Dan urutan kelima adalah weighted moving average yang mendapatkan nilai akurasi MAD sebesar
855.004; MSE sebesar 977.020.159.567 dan MAPE sebesar $26 \%$.

Peningkatan produksi dengan model terbaik dengan metode linier regression disajikan pada Gambar 2 di bawah ini.

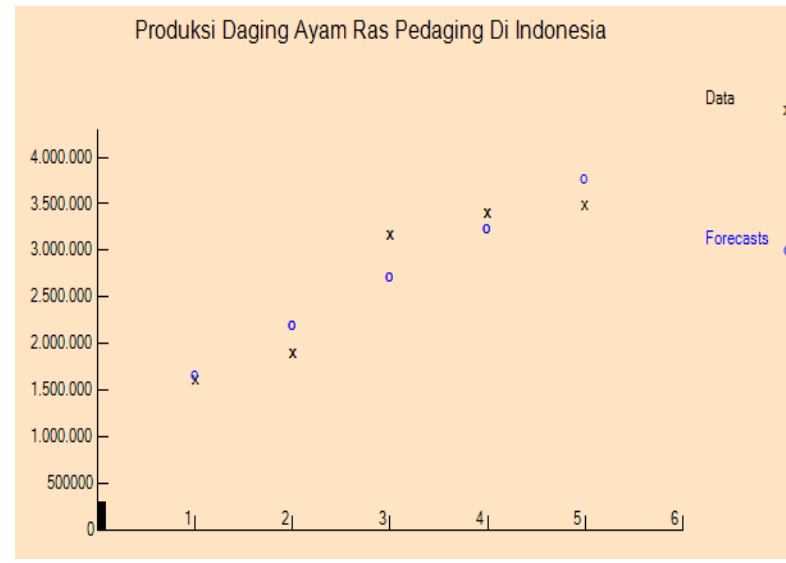

Gambar 2. Perbandingan antara data hasil pemodelan dengan nilai real

Peningkatan tersebut antara lain disebabkan oleh: (1) Masih adanya peningkatan permintaan pasar domestik meskipun dengan laju yang melambat, terutama untuk tujuan pusat-pusat pasar seperti Jakarta, Bogor, Tangerang, Bekasi serta kota-kota provinsi dan kabupaten, serta tumbuhnya pasar modern di samping pasar tradisional; (2) Industri pembibitan dan pakan ternak ayam ras pedaging telah berkembang secara mantap di dalam negeri; (3) Berkembangnya usaha ternak ayam ras pedaging baik skala kecil, menengah maupun skala besar yang semuanya diusahakan secara intensif; (4) Pengusahaan ternak ayam ras pedaging yang makin intensif dengan skala usaha yang makin besar; dan (5) Adanya pertumbuhan populasi di daerah-daerah pertumbuhan baru, seperti Sumatera Barat, Bengkulu, Sulawesi Utara, Sulawesi Tengah, Gorontalo dan Papua dengan pertumbuhan yang cukup tinggi (Nasution dan Prasetyawan, 2008).

\section{Konsumsi Daging Ayam Ras Pedaging di Indonesia}

Konsumsi daging ayam ras pedaging Indonesia dari tahun 2014- 2017 secara umum terus mengalami peningkatan setiap tahunnya dan terjadi penurunan di tahun 2018. Adapun angka kenaikan dan penurunan konsumsi ditunjukkan pada Gambar 3. 
Konsumsi daging ayam ras ini jika dilihat dari grafik menunjukkan bahwa peningkatan yang terjadi dari tahun ke tahun seimbang dengan meningkatnya produksi daging ayam ras di Indonesia. Rata- rata peningkatan yang terjadi dari tahun 2014- 2017 yakni sebesar 12,92 \%. Namun pada tahun 2018 terjadi penurunan konsumsi sebesar 1,83 \% tanpa diikuti penurunan jumlah produksi. Situasi ini mengakibatkan surplus pada pasokan daging di pasaran.

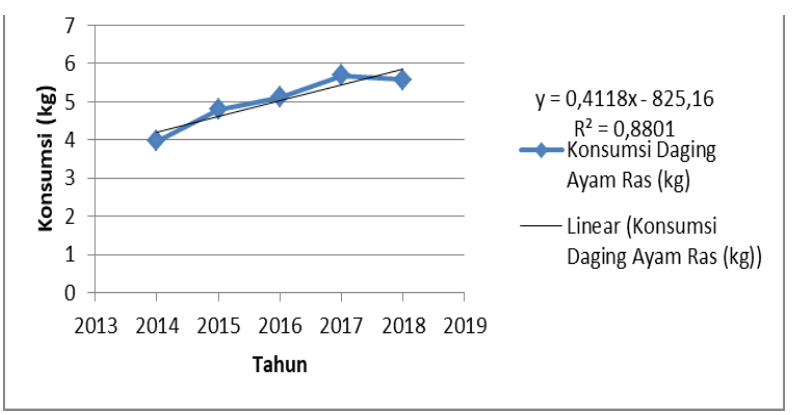

Gambar 3. Konsumsi daging ayam ras pedaging di Indonesia tahun 2014- 2018 (Ditjen. PKH)

Menurut Jahrona et. al. (2018) dalam penelitiannya bahwa faktor yang mempengaruhi konsumsi daging ayam ras yaitu harga daging ayam, produksi daging ayam dan tingkat pendapatan. Sejalan dengan Wirabrata (2019), daya beli masyarakat terhadap daging ayam ras disebabkan oleh harga yang dimainkan oleh mafia kartel ayam sehingga akan berdampak pada tingkat konsumsi masyarakat terhadap daging ayam ras.

Kondisi yang fluktuatif ini mendorong penulis untuk melakukan peramalan terhadap konsumsi daging ayam ras di tahun berikutnya. Peramalan konsumsi daging ayam ras merupakan salah satu tolok ukur keberlangsungan peternak ayam ras pedaging dan kesuksesan perwujudan ketahanan pangan Indonesia lewat pemenuhan protein dalam negeri. Peramalan dilakukan dengan cara melibatkan data konsumsi daging ayam ras masyarakat Indonesia oleh Ditjen. PKH di masa lalu dan memproyeksikannya ke masa yang akan datang dengan menggunakan Software POM-QM for Windows Version 3. Data yang digunakan untuk melakukan peramalan yaitu data konsumsi per kapita per tahun pada tahun 2014-2018. Perhitungan Software POM-QM for Windows Version 3 pada peramalan konsumsi daging ayam ras menggunakan metode linear regression, moving average, wighted moving average, eksponential smoothing, dan eksponential smoothing with trend.
Hasil perhitungan peramalan disajikan pada Tabel 2 berikut dibawah ini.

Tabel 2. Hasil peramalan/Pemodelan konsumsi daging ayam ras pedaging di Indonesia

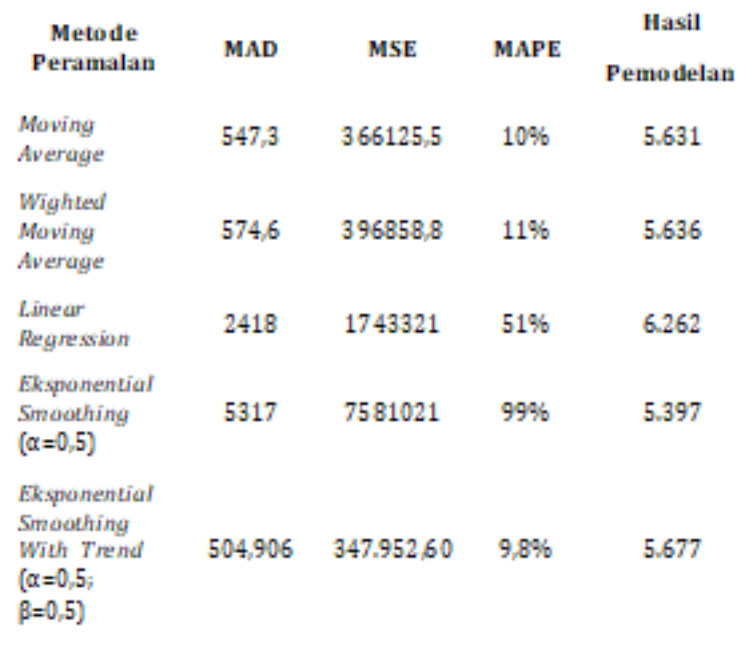

Berdasarkan Tabel 2, dapat diketahui bahwa metode eksponential smoothing with trend memiliki nilai MAD, MSE, dan MAPE terkecil dari metode lainnya yaitu sebesar 504,906; 347.952,60 dan 9,8\% dengan hasil peramalan konsumsi daging ayam ras pedaging pada tahun 2019 sebesar 5,677 kg per kapita per tahun. Penetapan tersebut dilihat dari nilai terendah dari MAD, MSE dan MAPE. Metode yang memiliki tingkat eror yang lebih kecil menandakan bahwa metode tersebut merupakan metode peramalan yang lebih akurat. Dengan demikian konsumsi daging ayam ras pedaging pada tahun 2020 yakni sebesar 5,708 kg per kapita per tahun.

Metode eksponential smoothing with trend merupakan metode peramalan yang paling tepat digunakan peternak ayam untuk memprediksi konsumsi daging ayam ras pedaging di masa yang akan datang. Hasil penelitian Yogi (2018), peramalan konsumsi daging ayam ras dengan metode double exponential smoothing lebih akurat dibandingkan model ARIMA. Metode double exponential smoothing dengan nilai MAPE sebesar 2,499 mengindikasikan bahwa konsumsi daging ayam ras dari tahun 2019 ke 2020 cenderung mengalami peningkatan sebesar 14,96\%. dipertegas oleh Damayanti (2017), proyeksi permintaan daging ayam broiler di Kota Malang pada tahun 2016 - 2020 dengan menggunakan 
metode double exponential smoothing dua parameter Holt memberikan trend yang positif (meningkat). Peningkatan tersebut diperkirakan dapat mewujudkan ketahanan pangan Indonesia melalui pemenuhan konsumsi protein dari daging ayam ras.

Penelitian lain yang dilakukan oleh Pratama dan Salamah (2018) menunjukkan bahwa peramalan dengan metode double exponential smoothing dapat meningkatkan kinerja Dinas Pertanian Kabupaten Aceh Utara menjadi lebih efektif dan efisien dalam meramalkan stok jenis komoditi tanaman pangan beberapa tahun kedepan. Pujiati et. al. (2016), peramalan indeks harga konsumen Kota Samarinda dengan metode double exponential smoothing dari bulan Januari Maret 2015 mengalami peningkatan tiap bulannya secara berturut-turut sebesar 121,44; 123,06 dan 124,68 .

Peramalan menggunakan metode exponential smoothing with trend pada tingkat konsumsi daging ayam ras pedaging oleh masyarakat di Indonesia mengalami peningkatan secara terus menerus pada tahun 2019 dan 2020 yakni sebesar $1,76 \%$ dan $0,55 \%$. Peningkatan tersebut dapat dilihat pada grafik hasil peramalan di bawah ini (Gambar 4).

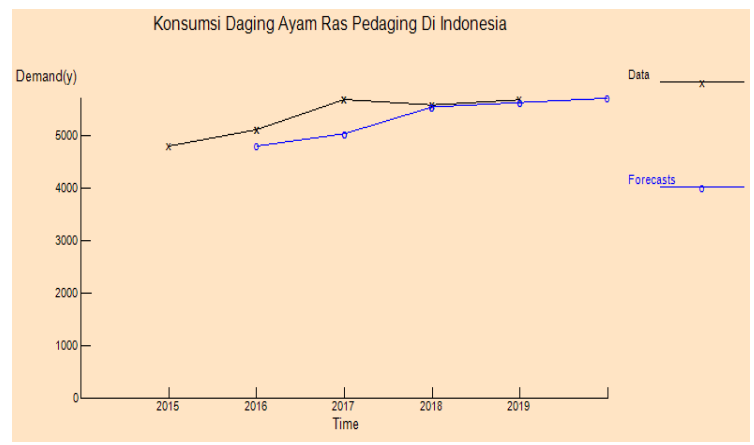

Gambar 4. Peramalan/Pemodelan konsumsi daging ayam ras pedaging di Indonesia

\section{Proyeksi Produksi Dan Konsumsi}

Metode peramalan yang terpilih baik dari produksi maupun konsumsi diharapkan dapat membantu para peternak ayam ras pedaging dalam perencanaan pengelolaan dan pemasaran. Harapan lain juga ditujukan untuk mewujudkan ketahanan pangan Indonesia dengan pemenuhan asupan protein secara mandiri dengan konsumsi daging ayam ras pedaging. Menurut Suharyanto (2011), ketahanan pangan di Indonesia diwujudkan dengan adanya ketersediaan pangan dalam jumlah dan jenis yang cukup, distribusi yang merata dan lancar serta konsumsi pangan dengan angka kecukupan gizi yang seimbang.

Berikut ini hasil proyeksi pada tahun 20202022 dari peramalan produksi dengan metode liniear regression dan konsumsi dengan metode eksponential smoothing with trend.

Tabel 3. Proyeksi produksi dan konsumsi daging ayam ras di Indonesia tahun 2020- 2022

\begin{tabular}{|c|c|c|}
\hline Tahun & $\begin{array}{c}\text { Produksi } \\
\text { Daging Ayam } \\
\text { Ras (ribu ton) }\end{array}$ & $\begin{array}{c}\text { Konsumsi Daging } \\
\text { Ayam Ras Per } \\
\text { Kapita (kg) }\end{array}$ \\
\hline $\mathbf{2 0 2 0}$ & 4.294 & 5,708 \\
\hline $\mathbf{2 0 2 1}$ & 4.784 & 5,730 \\
\hline $\mathbf{2 0 2 2}$ & 5.062 & 5,724 \\
\hline
\end{tabular}

\section{Kesimpulan}

Metode peramalan terbaik untuk produksi daging ayam ras adalah menggunakan metode liniear regression dengan nilai MAD sebesar 246.370; MSE sebesar 79.190.061.604 dan MAPE sebesar 9\%. Sedangkan peramalan konsumsi daging ayam ras menggunakan metode eksponential smoothing with trend dengan nilai MAD sebesar 504,906; MSE sebesar 347.952,60 dan MAPE sebesar 9,8\%. Proyeksi produksi daging ayam ras pada tahun 2020 - 2022 secara berturutturut yaitu sebesar 4.294.150 ton, 4.784 .994 ton, dan 5.062.790 ton. Sedangkan konsumsi daging ayam ras per kapita per tahun pada tahun 20202022 secara berturut- turut yaitu sebesar $5,708 \mathrm{~kg}$; $5,730 \mathrm{~kg}$; dan 5,724 kg.

\section{DAFTAR PUSTAKA}

Aritonang, R. Lerbin. (2002). Peramalan Bisnis. Jakarta: Penerbit Ghalia Indonesia.

Assauri, S. (2004). Manajemen Produksi dan Operasi. Jakarta: Fakultas Ekonomi Universitas Indonesia.

Baroto, T. (2002). Perencanaan dan Pengendalian Produksi. Jakarta: Ghalia Indonesia.

Damayanti, S. A. (2017). Analisis Peramalan Permintaan Daging Ayam Broiler Di Kota 
Malang Jawa Timur. Tesis. Universitas Brawijaya, Malang.

Direktorat Jenderal Peternakan dan Kesehatan Hewan. (2019). Statistik Peternakan Dan Kesehatan Hewan 2019. Kementerian Pertanian RI. ISSBN : 978-979-628-037-7.

Handoko, T. H. (2014). Dasar Dasar Manajemen Produksi dan Operasi. Yogyakarta: BPFEYogyakarta.

Indrajit, R. E., \& Djokopranoto, R. (2003). Manajemen Persediaan Barang Umum dan Suku Cadang Untuk Keperluan Pemeliharaan Perbaikan dan Operasi. Jakarta: PT. Grasindo.

Jahrona, L., Lubis, S. N., \& Hasyim H. (2018). Faktor - Faktor Yang Mempengaruhi Permintaan Daging Ayam Broiler Di Provinsi Sumatera Utara. Jurnal. Fakultas Pertanian Universitas Sumatera Utara. Medan.

Kementrian Perdagangan. (2014). Analisis Outlook Pangan 2015-2019 . Pusat Kebijakan Perdagangan Dalam Negeri. Badan Pengkajian Dan Pengembangan Kebijakan Perdagangan Kebijakan Perdagangan. Kementrian Perdagangan.

Nasution, A. H., \& Prasetyawan, Y. (2008). Perencanaan dan Pengendalian Produksi Edisi Pertama. Jakarta: Graha Ilmu.

Pratama, A., \& Salamah. (2018). Implementasi Sistem Informasi Peramalan Stok Jenis Komoditi Tanaman Pangan Di Aceh Utara. Jurnal Konferensi Nasional Teknologi Informasi dan Komputer. Vol. 2(1).

Pujiati, E., Yuniarti, D., \& Goejantoro , R. (2016). Peramalan Dengan Menggunakan Metode Double Exponential Smoothing Dari Brown (Studi Kasus: Indeks Harga Konsumen (IHK) Kota Samarinda) Forecasting Using Double Exponential Smoothing Method of Brown (Case Study: The Consumer Price Index (CPI) City Samarinda). Jurnal EKSPONENSIAL. Vol. $7(1)$.

Rangkuti, F. (2004). Manajemen Persediaan Aplikasi di Bidang Bisnis. Jakarta: PT. Raja Grafindo Persada.

Subagya, M. (1994). Manajemen Logistik. Jakarta: PT. Gunung Agung.

Suharyanto, H. (2011). Ketahanan Pangan. Jurnal Sosial Humaniora. Vol. 4(2).

Wirabrata, A. (2019). Anjloknya Harga Ayam Broiler. Jurnal Bidang Ekonomi dan Kebijakan Publik. Kajian Singkat Terhadap Isu Aktual Dan Strategis. Vol XI (13).
Yogi, I. N. S. (2018). Peramalan Produksi dan Konsumsi serta Analisis Permintaan Daging Ayam Ras Dalam Rangka Mempertahankan Swasembada Daging Ayam di Indonesia. Jurnal Matematika, Statistik dan Komputasi. Vol. 15(1): 21-36. 